\title{
Head-to-head evaluation of $\left[{ }^{18} \mathrm{~F}\right] \mathrm{FDG}$ and $\left[{ }^{68} \mathrm{Ga}\right] \mathrm{Ga}$-DOTA-FAPI-04 PET/ $\mathrm{CT}$ in recurrent soft tissue sarcoma
}

\author{
Bingxin $\mathrm{Gu}^{1,2,3,4,5} \cdot$ Xin $\mathrm{Liu}^{6} \cdot$ Shuoer Wang ${ }^{7}$. Xiaoping $\mathrm{Xu}^{1,2,3,4,5} \cdot$ Xiaosheng $\mathrm{Liu}^{1,2,3,4,5}$. Silong $\mathrm{Hu}^{1,2,3,4,5}$.

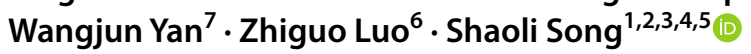

Received: 26 September 2021 / Accepted: 20 January 2022 / Published online: 3 February 2022

(c) The Author(s) 2022

\begin{abstract}
Purpose We aimed to evaluate the value of $\left[{ }^{68} \mathrm{Ga}\right] \mathrm{Ga}$-DOTA-FAPI-04 PET/CT for the diagnosis of recurrent soft tissue sarcoma (STS), compared with $\left[{ }^{18} \mathrm{~F}\right] \mathrm{FDG}$ PET/CT.

Methods A total of 45 patients (21 females and 24 males; median age, 46 years; range, 18-71 years) with 13 subtypes of STS underwent $\left[{ }^{18}\right.$ F]FDG and $\left[{ }^{68} \mathrm{Ga}\right] \mathrm{Ga}$-DOTA-FAPI-04 PET/CT examination within 1 week for assessment local relapse or distant metastasis. Positive lesions on PET/CT images were verified by biopsy or 3-month follow-up. Wilcoxon matched-pairs signed-rank test was used to compare the semiquantitative values ( $\mathrm{SUV}_{\max }$ and TBR) of $\left[{ }^{18} \mathrm{~F}\right] \mathrm{FDG}$ and $\left[{ }^{68} \mathrm{Ga}\right] \mathrm{Ga}-\mathrm{DOTA}-$ FAPI-04 in tumor lesions, and McNemar test was applied to test for differences of both tracers.

Results Among the 45 patients, 282 local relapses and distant metastases were identified. Compared to $\left[{ }^{18} \mathrm{~F}\right] \mathrm{FDG},\left[{ }^{68} \mathrm{Ga}\right]$ Ga-DOTA-FAPI-04 PET/CT detected more lesions (275 vs. 186) and outperformed in sensitivity, specificity, PPV, NPV, and accuracy for the diagnosis of recurrent lesions $(P<0.001)$. $\left[{ }^{68} \mathrm{Ga}\right] \mathrm{Ga}$-DOTA-FAPI-04 demonstrated significantly higher values of $\mathrm{SUV}_{\max }$ and TBR than $\left[{ }^{18} \mathrm{~F}\right] \mathrm{FDG}$ PET/CT in liposarcoma $(P=0.011$ and $P<0.001$, respectively), malignant solitary fibrous tumor (MSFT) $(P<0.001$ and $P<0.001$, respectively), and interdigitating dendritic cell sarcoma (IDCS) $\left(P<0.001\right.$ and $P<0.001$, respectively). While mean $\mathrm{SUV}_{\max }$ and TBR presented favorable uptake of $\left[{ }^{18} \mathrm{~F}\right] \mathrm{FDG}$ over $\left[{ }^{68} \mathrm{Ga}\right]$ Ga-DOTA-FAPI-04 in undifferentiated pleomorphic sarcoma (UPS) $(P=0.003$ and $P<0.001$, respectively) and rhabdomyosarcoma (RMS) $(P<0.001$ and $P<0.001$, respectively).

Conclusion $\left[{ }^{68} \mathrm{Ga}\right] \mathrm{Ga}$-DOTA-FAPI-04 PET/CT is a promising new imaging modality for recurrent surveillance of STS, and compares favorably with $\left[{ }^{18} \mathrm{~F}\right] \mathrm{FDG}$ for identifying recurrent lesions of liposarcoma, MSFT, and IDCS.
\end{abstract}

Keywords FAPI $\cdot$ FDG $\cdot$ Soft tissue sarcoma $\cdot$ PET/CT $\cdot$ SUV

\section{Introduction}

Bingxin $\mathrm{Gu}$ and Xin Liu contributed equally to this work.

This article is part of the Topical Collection on OncologyMuskoskeletal

Zhiguo Luo

luozhiguo88@163.com

Shaoli Song

shaoli-song@163.com

1 Department of Nuclear Medicine, Fudan University Shanghai Cancer Center, Shanghai, China

2 Department of Oncology, Shanghai Medical College, Fudan University, Shanghai, China

3 Center for Biomedical Imaging, Fudan University, Shanghai, China
Soft tissue sarcomas (STS) are rare and heterogeneous tumors, which contain more than 50 different histologic subtypes according to the World Health Organization (WHO)

4 Shanghai Engineering Research Center of Molecular Imaging Probes, Shanghai, China

5 Key Laboratory of Nuclear Physics and Ion-Beam Application (MOE), Fudan University, Shanghai, China

6 Department of Medical Oncology, Fudan University Shanghai Cancer Center, Shanghai, China

7 Department of Musculoskeletal Tumor, Fudan University Shanghai Cancer Center, Shanghai, China 
classification [1]. The prognosis of metastatic STS is dismal, with a median overall survival (OS) of 8-12 months [2]. Thus, optimal imaging of STS is crucial for accurately restaging and detecting local relapse and/or distant metastasis as early and as completely as possible. The most frequent metastatic sites of STS are the lung, followed by bone and lymph nodes [3]. Computed tomography (CT) and magnetic resonance imaging (MRI) serve as the routine means for local relapsed surveillance. But for detecting distant metastasis, $\left[{ }^{18} \mathrm{~F}\right]$-fluorodeoxyglucose $\left(\left[{ }^{18} \mathrm{~F}\right] \mathrm{FDG}\right)$ positron emission tomography/computed tomography (PET/CT) shows higher sensitivity and accuracy [4]. Furthermore, $\left[{ }^{18} \mathrm{~F}\right] \mathrm{FDG}$ PET/CT is useful for initial staging and restaging, evaluation of treatment response, and predicting treatment efficacy and clinical outcome for STS [5]. However, due to lack of sensitivity among some subtypes of sarcomas, particularly low-grade sarcomas, $\left[{ }^{18} \mathrm{~F}\right] \mathrm{FDG}$ PET/CT is not generally recommended for the management of sarcomas [6-8].

Recently, new development of PET tracers targeting fibroblast activation protein (FAP), $\left[{ }^{68} \mathrm{Ga}\right]$-fibroblast activation protein inhibitor (FAPI), had shown promising results in imaging of sarcomas [9]. FAP is a type II membrane-bound glycoprotein belonging to the dipeptidyl peptidase 4 family, which has both dipeptidyl peptidase and endopeptidase activity. FAP plays a pivotal role in tumor microenvironment, including reduced levels of anti-angiogenic factors, elevated levels of transforming growth factor $\beta$, and affected matrix processing enzymes [10]. FAP is overexpressed in cancer-associated fibroblasts (CAFs) in the stroma of more than $90 \%$ of epithelial carcinomas [11] and many subtypes of STS (e.g., fibrosarcoma, malignant fibrous histiocytoma, and liposarcoma) [12, 13]. In addition to diagnostic imaging, FAP is also considered as a promising target for delivering therapeutic nuclide [14]. This may provide a new approach for recurrent STS to improve survival. Thus, the expression of FAP on different STS needs to be identified.

Inspired by the promising results of $\left[{ }^{68} \mathrm{Ga}\right] \mathrm{Ga}$-DOTAFAPI-04 imaging on many epithelial carcinomas $[9,15,16]$, we hypothesized that $\left[{ }^{68} \mathrm{Ga}\right] \mathrm{Ga}-\mathrm{DOTA}-F A P I-04$ would outperform $\left[{ }^{18} \mathrm{~F}\right] \mathrm{FDG}$ in recurrent surveillance of STS. Herein, in this study, we aimed to investigate the potential usefulness of $\left[{ }^{68} \mathrm{Ga}\right] \mathrm{Ga}$-DOTA-FAPI-04 PET/CT for the diagnosis of recurrent lesions in patients with STS, compared with $\left[{ }^{18} \mathrm{~F}\right] \mathrm{FDG}$ $\mathrm{PET} / \mathrm{CT}$. The primary objective of this study was the comparison of uptake of $\left[{ }^{18}\right.$ F]FDG and $\left[{ }^{68} \mathrm{Ga}\right] \mathrm{Ga}$-DOTA-FAPI-04 by different histological STS subtypes. Secondary objectives were the comparison by grading and by lesion location.

\section{Methods}

\section{Patient selection}

This prospective clinical trial (CFFSTS Trial, ChiCTR2100053984, Chinese Clinical Trial Registry) was conducted in Fudan University Shanghai Cancer Center to compare the diagnostic ability of $\left[{ }^{68} \mathrm{Ga}\right.$ ]Ga-DOTAFAPI-04 and $\left[{ }^{18}\right.$ F]FDG PET/CT in patients with STS from May 2020. To further investigate the role of $\left[{ }^{68} \mathrm{Ga}\right]$ Ga-DOTA-FAPI-04 in recurrent STS, inclusion criteria were as follows: (i) pathologically confirmed STS; (ii) patients were suspected recurrence after radical treatment. The exclusion criteria were (i) patients without recurrence; (ii) patients with two or more malignant tumor history; and (iii) patients unwilling to take $\left[{ }^{18} \mathrm{~F}\right] \mathrm{FDG}$ and $\left[{ }^{68} \mathrm{Ga}\right]$ Ga-DOTA-FAPI-04 PET/CT. Data including demographics, tumor characteristics, and treatment information were collected from the medical records. This prospective study was approved by Fudan University Shanghai Cancer Center Institutional Review Board (ID 2,004,216-25) and conducted in accordance with the 1964 Declaration of Helsinki and its later amendments or comparable ethical standards. Informed consents to undergo $\left[{ }^{18} \mathrm{~F}\right] \mathrm{FDG}$ and $\left[{ }^{68} \mathrm{Ga}\right] \mathrm{Ga}$-DOTA-FAPI-04 PET/CT were obtained from all enrolled patients.

\section{Radiopharmaceuticals and PET/CT scanning procedure}

$\left[{ }^{18} \mathrm{~F}\right] \mathrm{FDG}$ was produced automatically using Explora $\mathrm{FDG}_{4}$ module with cyclotron (Siemens CTI RDS Eclips ST, Knoxville, Tennessee, USA) in our center. DOTAFAPI-04 was obtained commercially (Jiangsu Huayi Technology CO., LTD, Jiangsu, China). DOTA-FAPI-04 was radiolabeled with ${ }^{68} \mathrm{Ga}$ according to Lindner et al. [14]. Briefly, the DOTA-FAPI-04 and ${ }^{68}$ Ga-solution (elution with $0.5 \mathrm{M} \mathrm{HCl}$ ) were mixed with sodium acetate, and the $\mathrm{pH}$ was maintained about 4.5 . Then the reaction mixture was heated to $100{ }^{\circ} \mathrm{C}$ for $20 \mathrm{~min}$. The $\left[{ }^{68} \mathrm{Ga}\right] \mathrm{Ga}$-DOTAFAPI-04 was obtained by solid phase extraction. Radiochemical purity of $\left[{ }^{18} \mathrm{~F}\right] \mathrm{FDG}$ and $\left[{ }^{68} \mathrm{Ga}\right] \mathrm{Ga}$-DOTAFAPI-04 was both over $95 \%$.

$\left[{ }^{18} \mathrm{~F}\right]$ FDG and $\left[{ }^{68} \mathrm{Ga}\right] \mathrm{Ga}-\mathrm{DOTA}-F A P I-04$ PET/CT scans were performed within 1 week. For $\left[{ }^{18} \mathrm{~F}\right] \mathrm{FDG}$ PET/CT scanning, patients fasted at least $6 \mathrm{~h}$, maintaining venous blood glucose levels under $10 \mathrm{mmol} / \mathrm{L}$ prior to $\left[{ }^{18} \mathrm{~F}\right] \mathrm{FDG}$ administration. But this was not necessary for [ $\left.{ }^{68} \mathrm{Ga}\right] \mathrm{Ga}-\mathrm{DOTA}-F A P I-04$ PET/CT scanning. After injecting with $242.62 \pm 43.83 \mathrm{MBq}$ of $\left[{ }^{18} \mathrm{~F}\right] \mathrm{FDG}$ or $147.69 \pm 21.55 \mathrm{MBq}$ of $\left[{ }^{68} \mathrm{Ga}\right] \mathrm{Ga}$-DOTA-FAPI-04, 
patients were kept in a quiet environment for approximately 60 min prior to examination. No adverse or clinically detectable pharmacological effects were observed in any of these patients. All images were obtained on a Biograph mCT Flow scanner (Siemens Medical Solutions). Low-dose CT scanning was performed firstly for location: scanning ranging from the proximal thighs or feet to head, with $120 \mathrm{kV}, 100 \mathrm{mAs}$, CARE Dose4D, slice thickness $3 \mathrm{~mm}$, increment $2 \mathrm{~mm}$, pitch 1.0 , rotation time $0.5 \mathrm{~s}$, and soft-tissue reconstruction kernel. Immediately after CT scanning, a PET emission scan that covered the corresponding field of CT was acquired in 3-dimensional mode using FlowMotion with a speed of 2 . The emission data were corrected for random scatter and decay. PET image datasets were reconstructed iteratively using an orderedsubset expectation maximization iterative reconstruction by applying CT data for attenuation correction. Fusion images were reviewed and manipulated on a multimodality computer platform (Syngo, Siemens, Knoxville, Tennessee, USA). Two experienced nuclear medicine physicians analyzed and interpreted the images independently, and they reached a consensus in case of inconsistency.

Increased radioactivity of relapsed or metastatic lesions compared with the uptake of surrounding normal tissue was defined as being positive, verified by biopsy or 3-month follow-up. Lesions were considered malignant during follow-up based on (i) typical malignant features (i.e., mass, abnormal density, poor circumscription, and destruction), and (ii) a significant reduction or progression in size after anticancer treatment confirmed by follow-up imaging (i.e., CT and MRI) according to RECIST 1.1 [17]. For quantitative analysis, maximum and mean of standardized uptake value (SUV) normalized to body weight were manually computed for tumor lesions and healthy tissues by drawing a 3-dimensional volume of interest, respectively. Meanwhile, tumorto-background ratio (TBR) for tumor lesions was calculated according to the formula: TBR $=\mathrm{tSUVmax} / \mathrm{bSUVmean}$, where tSUVmax is the maximum SUV of tumor lesion, and bSUVmean is the mean SUV of normal tissue.

\section{Statistical analyses}

All statistical analyses were performed using SPSS 25.0 (IBM, Armonk, NY, USA). Mean with standard deviation or median with range was used to describe continuous characteristics. Sensitivity, specificity, positive predictive value (PPV), negative predictive value (NPV), and accuracy of $\left[{ }^{18} \mathrm{~F}\right] \mathrm{FDG}$ and $\left[{ }^{68} \mathrm{Ga}\right] \mathrm{Ga}-\mathrm{DOTA}-\mathrm{FAPI}-04$ were determined, and McNemar test was applied to test for differences of both tracers. To compare the semiquantitative values $\left(\mathrm{SUV}_{\text {max }}\right.$ and TBR) of $\left[{ }^{18} \mathrm{~F}\right] \mathrm{FDG}$ and $\left[{ }^{68} \mathrm{Ga}\right] \mathrm{Ga}$-DOTA-FAPI-04 in tumor lesions, Wilcoxon matched-pairs signed-rank test was used. Two-tailed $p<0.05$ was considered statistically significant.

\section{Results}

\section{Patients}

From May 2020 to May 2021, 45 patients (21 females and 24 males; median age $=46$ years, range, $18-71$ years) were consecutively enrolled in this study (Fig. 1). All patients were diagnosed with STS and got radical treatment (e.g., surgery, radiotherapy, chemotherapy, or combination therapy) before PET/CT scans. Diagnostic CT or MRI was performed in 30 out of 45 patients prior to PET/CT scans, and positive findings were observed in 29 patients (Table 1).

\section{Comparison of $\left[{ }^{18} \mathrm{~F}\right]$ FDG and $\left[{ }^{68} \mathrm{Ga}\right] \mathrm{Ga}$-DOTA-FAPI-04 PET/CT based on different subtypes of recurrent STS}

The representative figures of the 13 subtypes of recurrent STS are presented in Fig. 2. Overall, 282 local relapses and distant metastases were identified among the 45 patients. Among these lesions, 13 were verified by biopsy and 269

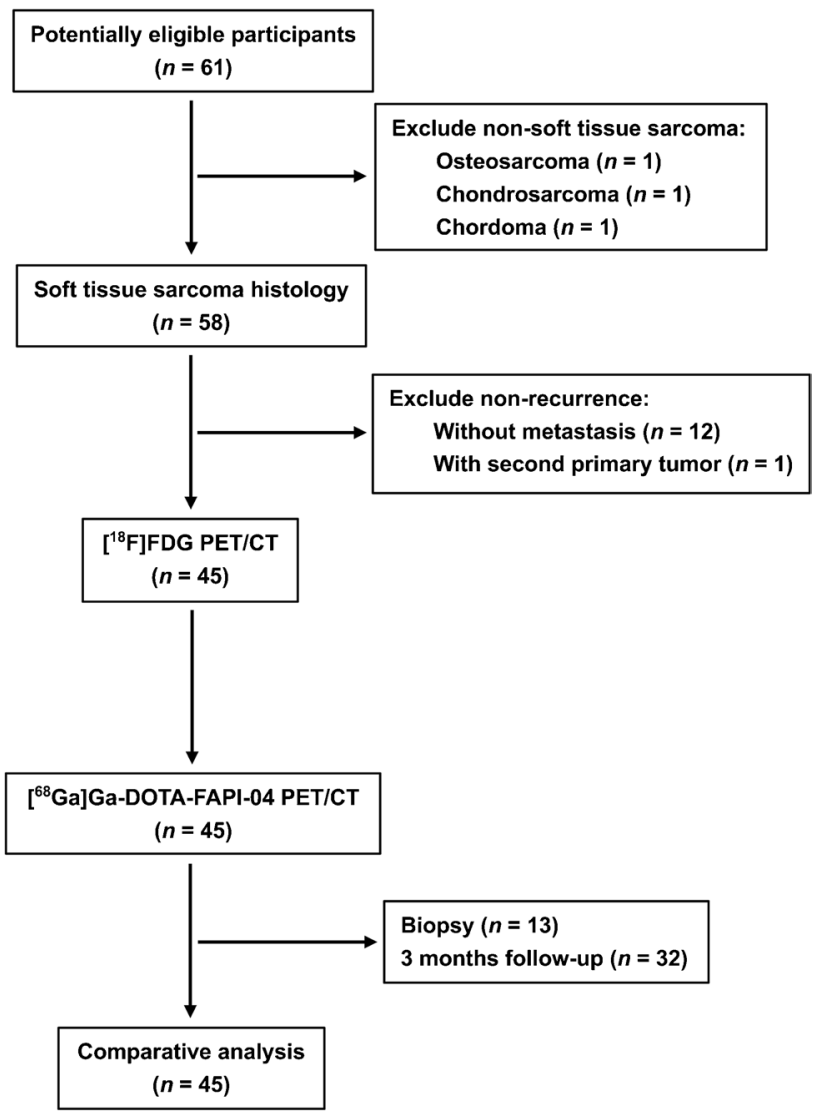

Fig. 1 Flowchart of patient selection 
Table 1 Detailed clinical characteristics of the patients

\begin{tabular}{|c|c|c|c|c|c|c|c|c|}
\hline \multirow[t]{2}{*}{ Patient } & \multirow[t]{2}{*}{ Gender } & \multirow[t]{2}{*}{ Age } & \multirow[t]{2}{*}{ Histology } & \multicolumn{2}{|l|}{ Initial treatment } & \multirow{2}{*}{$\begin{array}{l}\text { Diagnostic CT/MRI } \\
\text { before PET/CT scan* }\end{array}$} & \multicolumn{2}{|l|}{ Restaging } \\
\hline & & & & Localization & Grading & & FDG & FAPI-04 \\
\hline 1 & $\mathrm{~F}$ & 51 & UPS & Thigh & G3 & $\mathrm{CT}+$ & $\mathrm{LR}+\mathrm{DM}$ & $\mathrm{LR}+\mathrm{DM}$ \\
\hline 2 & M & 58 & UPS & Retroperitoneum & G3 & / & $\mathrm{LR}+\mathrm{DM}$ & $\mathrm{LR}+\mathrm{DM}$ \\
\hline 3 & M & 71 & UPS & Retroperitoneum & G3 & $\mathrm{CT}+$ & $\mathrm{LR}+\mathrm{DM}$ & $\mathrm{LR}+\mathrm{DM}$ \\
\hline 4 & M & 53 & UPS & Neck & G3 & MRI+ & LR & LR \\
\hline 5 & $\mathrm{~F}$ & 46 & UPS & Small intestine & G3 & I & LR & LR \\
\hline 6 & M & 63 & UPS & Retroperitoneum & G3 & I & $\mathrm{LR}+\mathrm{DM}$ & $\mathrm{LR}+\mathrm{DM}$ \\
\hline 7 & M & 22 & UPS & Inguinal & G3 & I & LR & LR \\
\hline 8 & $\mathrm{~F}$ & 64 & Well-differentiated liposarcoma & Retroperitoneum & G1 & $\mathrm{CT}+$ & $\mathrm{LR}+\mathrm{DM}$ & $\mathrm{LR}+\mathrm{DM}$ \\
\hline 9 & $\mathrm{~F}$ & 59 & Pleomorphic liposarcoma & Lower leg & G3 & $\mathrm{CT}+$ & $\mathrm{LR}+\mathrm{DM}$ & $\mathrm{LR}+\mathrm{DM}$ \\
\hline 10 & M & 67 & Well-differentiated liposarcoma & Retroperitoneum & G1 & / & LR & LR \\
\hline 11 & M & 70 & Dedifferentiated liposarcoma & Thigh & G3 & I & $\mathrm{DM}$ & DM \\
\hline 12 & $\mathrm{~F}$ & 39 & Dedifferentiated liposarcoma & Retroperitoneum & G3 & $\mathrm{CT}+$ & LR & LR \\
\hline 13 & $\mathrm{~F}$ & 36 & Well-differentiated liposarcoma & Retroperitoneum & G1 & MRI+ & Non-recurrence & LR \\
\hline 14 & M & 34 & Synovial sarcoma & Postmediastinum & G3 & $\mathrm{CT}+$ & LR & LR \\
\hline 15 & $\mathrm{~F}$ & 55 & Synovial sarcoma & Kidney & G3 & I & $\mathrm{LR}+\mathrm{DM}$ & $\mathrm{LR}+\mathrm{DM}$ \\
\hline 16 & M & 23 & Synovial sarcoma & Lung & G3 & $\mathrm{CT}+$ & LR & LR \\
\hline 17 & M & 38 & Synovial sarcoma & Abdomen & G3 & MRI+ & LR & LR \\
\hline 18 & $\mathrm{~F}$ & 65 & Synovial sarcoma & Lower leg & G3 & $\mathrm{CT}+$ & LR & LR \\
\hline 19 & M & 41 & Synovial sarcoma & Kidney & G3 & MRI+ & LR & $\mathrm{LR}+\mathrm{DM}$ \\
\hline 20 & M & 20 & RMS & Cheek & G3 & $\mathrm{CT}+$ & $\mathrm{DM}$ & $\mathrm{DM}$ \\
\hline 21 & $\mathrm{~F}$ & 29 & RMS & Perineum & G3 & MRI+ & $\mathrm{LR}+\mathrm{DM}$ & $\mathrm{LR}+\mathrm{DM}$ \\
\hline 22 & $\mathrm{~F}$ & 19 & RMS & Nasal cavity & G3 & $\mathrm{CT}-$ & $\mathrm{DM}$ & $\mathrm{DM}$ \\
\hline 23 & M & 25 & RMS & Nasal cavity & G3 & MRI+ & $\mathrm{DM}$ & $\mathrm{DM}$ \\
\hline 24 & $\mathrm{~F}$ & 18 & RMS & Perianal region & G3 & $\mathrm{MRI}+$ & $\mathrm{LR}+\mathrm{DM}$ & $\mathrm{LR}+\mathrm{DM}$ \\
\hline 25 & M & 47 & MSFT & Thigh & G2 & $\mathrm{CT}+$ & $\mathrm{LR}+\mathrm{DM}$ & $\mathrm{LR}+\mathrm{DM}$ \\
\hline 26 & M & 69 & MSFT & Retroperitoneum & Unknown & I & LR & $\mathrm{LR}+\mathrm{DM}$ \\
\hline 27 & M & 49 & MSFT & Neck & G1 & I & $\mathrm{DM}$ & $\mathrm{DM}$ \\
\hline 28 & $\mathrm{~F}$ & 65 & MSFT & Uterus & $\mathrm{G} 2$ & $\mathrm{CT}+$ & $\mathrm{LR}+\mathrm{DM}$ & $\mathrm{LR}+\mathrm{DM}$ \\
\hline 29 & M & 19 & Ewing sarcoma & Thigh & G3 & MRI+ & LR & LR \\
\hline 30 & M & 20 & Ewing sarcoma & Buttock & G3 & / & DM & $\mathrm{DM}$ \\
\hline 31 & M & 25 & Ewing sarcoma & Pelvic cavity & G3 & / & LR & LR \\
\hline 32 & $\mathrm{~F}$ & 29 & Ewing sarcoma & Perianal region & G3 & MRI+ & LR & LR \\
\hline 33 & $\mathrm{~F}$ & 60 & Leiomyosarcoma & Uterus & Unknown & $\mathrm{CT}+$ & $\mathrm{DM}$ & $\mathrm{DM}$ \\
\hline 34 & $\mathrm{~F}$ & 55 & Leiomyosarcoma & Uterus & Unknown & $\mathrm{CT}+$ & $\mathrm{DM}$ & $\mathrm{DM}$ \\
\hline 35 & $\mathrm{~F}$ & 47 & Leiomyosarcoma & Retroperitoneum & G2 & I & $\mathrm{LR}+\mathrm{DM}$ & $\mathrm{LR}+\mathrm{DM}$ \\
\hline 36 & $\mathrm{~F}$ & 51 & Leiomyosarcoma & Uterus & $\mathrm{G} 2$ & MRI+ & $\mathrm{DM}$ & $\mathrm{DM}$ \\
\hline 37 & M & 28 & Myxofibrosarcoma & Shoulder & G3 & $\mathrm{CT}+$ & $\mathrm{DM}$ & $\mathrm{DM}$ \\
\hline 38 & M & 46 & Myxofibrosarcoma & Waist & G2 & I & $\mathrm{DM}$ & DM \\
\hline 39 & M & 33 & Myxofibrosarcoma & Buttock & G1 & / & LR & $\mathrm{LR}$ \\
\hline 40 & $\mathrm{~F}$ & 47 & ASPS & Small intestine & G3 & MRI+ & $\mathrm{LR}+\mathrm{DM}$ & $\mathrm{LR}+\mathrm{DM}$ \\
\hline 41 & $\mathrm{~F}$ & 19 & ASPS & Abdomen & G3 & MRI+ & $\mathrm{LR}+\mathrm{DM}$ & $\mathrm{LR}+\mathrm{DM}$ \\
\hline 42 & $\mathrm{~F}$ & 66 & Epithelioid sarcoma & Inguinal & G3 & I & LR & LR \\
\hline 43 & $\mathrm{M}$ & 23 & Aggressive fibromatosis & Pelvic cavity & Unknown & $\mathrm{CT}+$ & LR & LR \\
\hline 44 & $\mathrm{~F}$ & 44 & FDCS & Liver & Unknown & $\mathrm{CT}+$ & $\mathrm{LR}+\mathrm{DM}$ & $\mathrm{LR}+\mathrm{DM}$ \\
\hline 45 & M & 48 & IDCS & Liver & Unknown & $\mathrm{CT}+$ & Non-recurrence & $\mathrm{LR}+\mathrm{DM}$ \\
\hline
\end{tabular}

* "+" means diagnostic CT/MRI could detect the relapsed or metastatic lesions, and "_" indicates diagnostic CT/MRI could not detect the relapsed or metastatic lesions. $F$, female; $M$, male; $U P S$, undifferentiated pleomorphic sarcoma; $R M S$, rhabdomyosarcoma; $M S F T$, malignant solitary fibrous tumor; ASPS, alveolar soft part sarcoma; FDCS, follicular dendritic cell sarcoma; IDCS, interdigitating dendritic cell sarcoma; $L R$, local relapse; $D M$, distant metastasis 


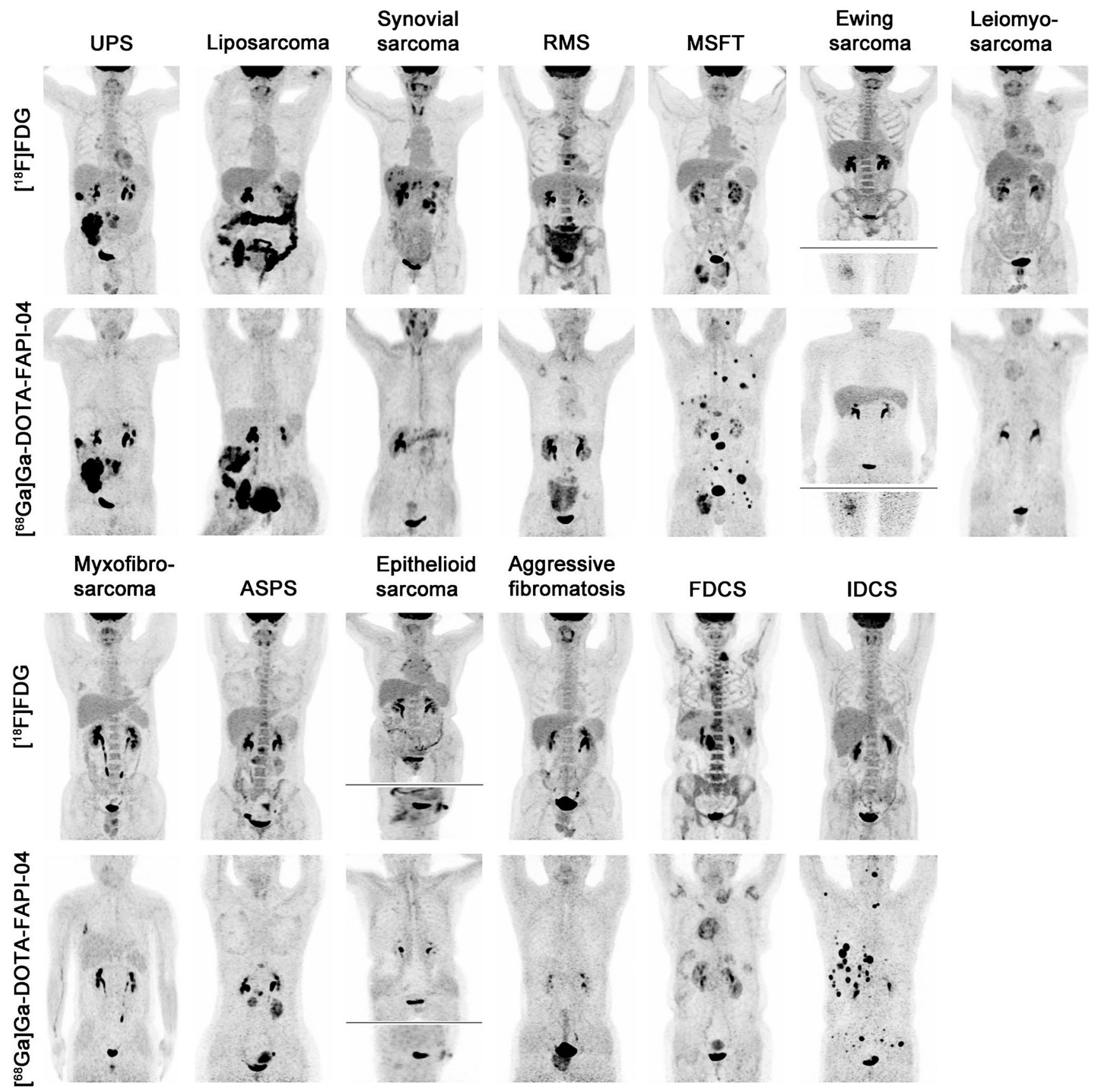

Fig. 2 MIP images of $\left[{ }^{18}\right.$ F]FDG PET/CT and $\left[{ }^{68}\right.$ Ga]Ga-DOTAFAPI-04 PET/CT in patients reflecting 13 different representative recurrent STS entities. MIP, maximum-intensity projection; STS, soft tissue sarcoma; UPS, undifferentiated pleomorphic sarcoma; RMS,

were assessed by follow-up imaging. Interestingly, $\left[{ }^{68} \mathrm{Ga}\right]$ Ga-DOTA-FAPI-04 PET/CT led to upstaging in 4 out of $45(8.89 \%)$ patients compared with $\left[{ }^{18} \mathrm{~F}\right] \mathrm{FDG}$ PET/CT (Table 1). In terms of different subtypes of recurrent STS, liposarcoma (Fig. 3), malignant solitary fibrous tumor (MSFT, Fig. 4), and interdigitating dendritic cell sarcoma (IDCS, Fig. 5) showed elevated uptake of [ $\left.{ }^{68} \mathrm{Ga}\right]$ Ga-DOTA-FAPI-04, and demonstrated significantly higher rhabdomyosarcoma; MSFT, malignant solitary fibrous tumor; ASPS, alveolar soft part sarcoma; FDCS, follicular dendritic cell sarcoma; IDCS, interdigitating dendritic cell sarcoma

semiquantitative values of $\mathrm{SUV}_{\max }$ and TBR than $\left[{ }^{18} \mathrm{~F}\right]$ FDG $\left(P=0.011,<0.001\right.$, and $<0.001$ for $\mathrm{SUV}_{\max }$, respectively; $P<0.001,<0.001$, and $<0.001$ for TBR, respectively; Table 2 and Table S1). Whereas, mean $\mathrm{SUV}_{\max }$ and TBR presented favorable uptake of $\left[{ }^{18} \mathrm{~F}\right] \mathrm{FDG}$ over $\left[{ }^{68} \mathrm{Ga}\right]$ Ga-DOTA-FAPI-04 in undifferentiated pleomorphic sarcoma (UPS) and rhabdomyosarcoma (RMS) $(P=0.003$ and $<0.001$ for $\mathrm{SUV}_{\max }$, respectively; $P<0.001$ and $<0.001$ 
a

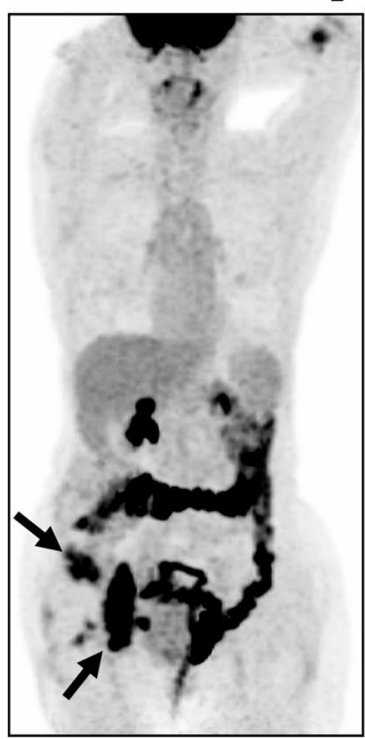

$\left[{ }^{18} \mathrm{~F}\right] \mathrm{FDG}$

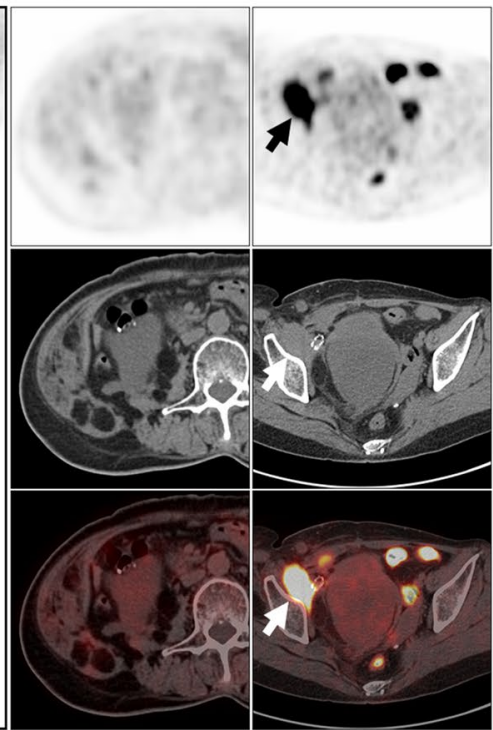

Fig. 3 A 64-year-old woman (patient \#8) pathologically confirmed with retroperitoneal well-differentiated liposarcoma received radical operation 4 years ago. $\left[{ }^{18} \mathrm{~F}\right] \mathrm{FDG}$ PET/CT (a) demonstrated pelvic wall metastatic foci with intensive metabolic activity. But the abdominal wall foci and large pelvic metastatic foci showed no intensive b $\quad\left[{ }^{68} \mathrm{Ga}\right] \mathrm{Ga}-\mathrm{DOTA}-\mathrm{FAPI}-04$

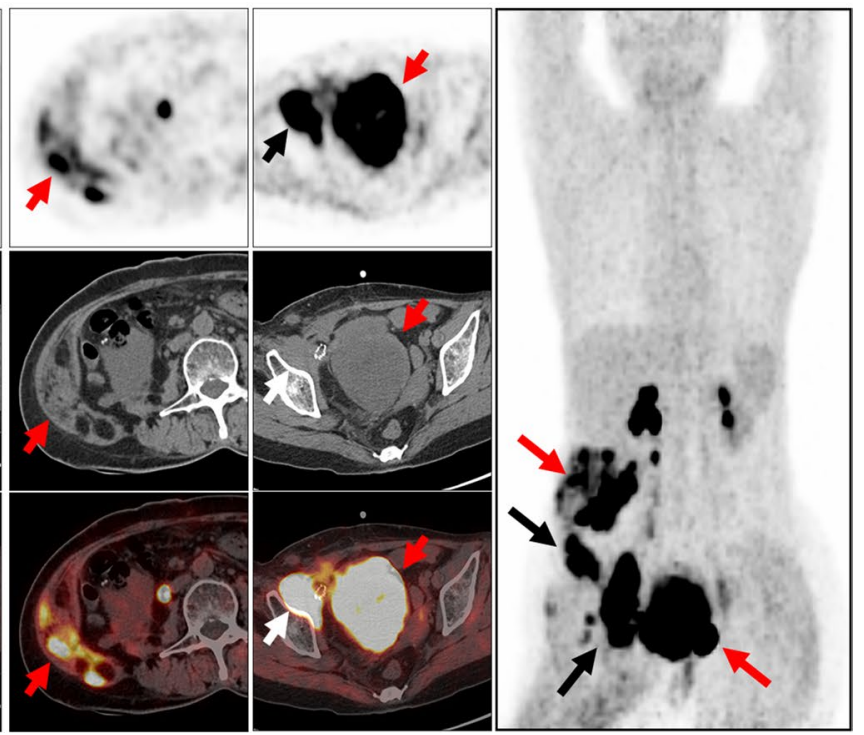

uptake of $\left[{ }^{18} \mathrm{~F}\right]$ FDG. Compared with $\left[{ }^{18} \mathrm{~F}\right] \mathrm{FDG},\left[{ }^{68} \mathrm{Ga}\right] \mathrm{Ga}$-DOTAFAPI-04 PET/CT (b) detected all the metastatic lesions with intense $\left[{ }^{68} \mathrm{Ga}\right] \mathrm{Ga}-\mathrm{DOTA}-\mathrm{FAPI}-04$ activity. Black and white arrows indicated the tumor lesions detected by both tracers, and red arrows indicated the tumor lesions detected by $\left[{ }^{68} \mathrm{Ga}\right] \mathrm{Ga}$-DOTA-FAPI-04 alone

a

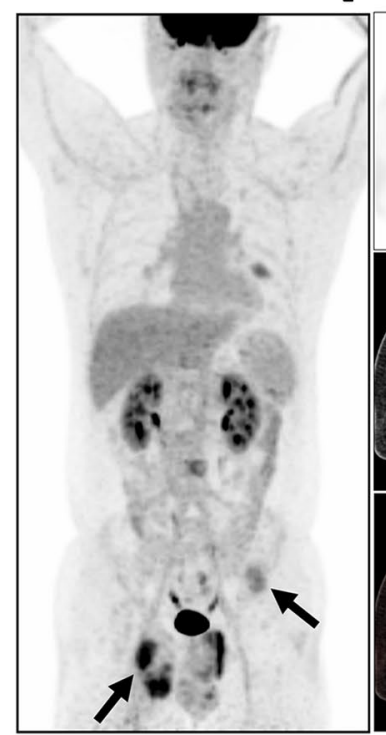

${ }^{18}$ FJPG

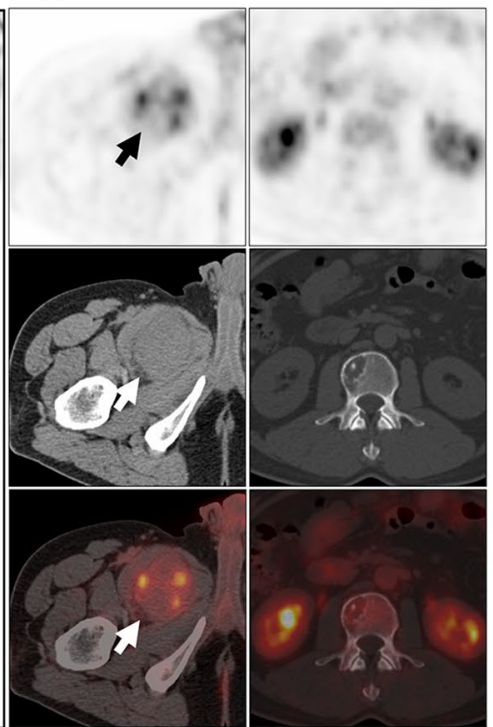

Fig. 4 A 47-year-old man (patient \#25) pathologically confirmed with malignant solitary fibrous tumor (MSFT) arising from right the thigh received radical operation 1 year ago. $\left[{ }^{18}\right.$ F]FDG PET/CT (a) demonstrated the relapse of right thigh and some bone metastases with low metabolic activity. Compared with $\left[{ }^{18} \mathrm{~F}\right] \mathrm{FDG},\left[{ }^{68} \mathrm{Ga}\right] \mathrm{Ga}-\mathrm{DOTA}-$ FAPI-04 PET/CT (b) demonstrated more metastases, including lung,

\section{b $\quad\left[{ }^{68} \mathrm{Ga}\right] \mathrm{Ga}-\mathrm{DOTA}-\mathrm{FAPI}-04$}

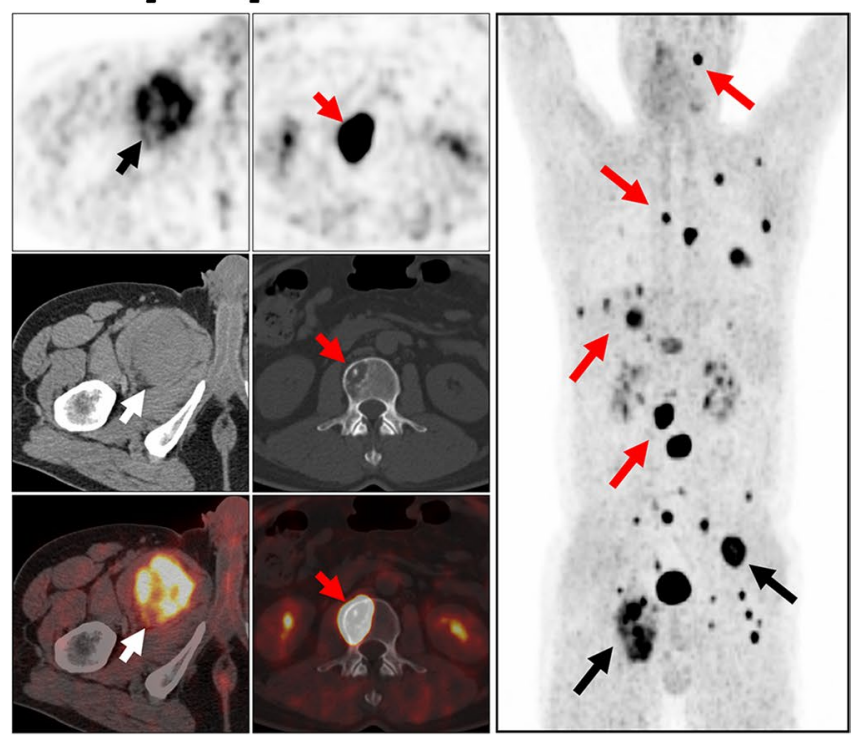

bone, and liver metastases. Moreover, all the relapse and metastases showed intensive uptake of $\left[{ }^{68} \mathrm{Ga}\right] \mathrm{Ga}-\mathrm{DOTA}-\mathrm{FAPI}-04$. Black and white arrows indicated the tumor lesions detected by both tracers, and red arrows indicated the tumor lesions detected by [ $\left.{ }^{68} \mathrm{Ga}\right] \mathrm{Ga}$-DOTAFAPI-04 alone 


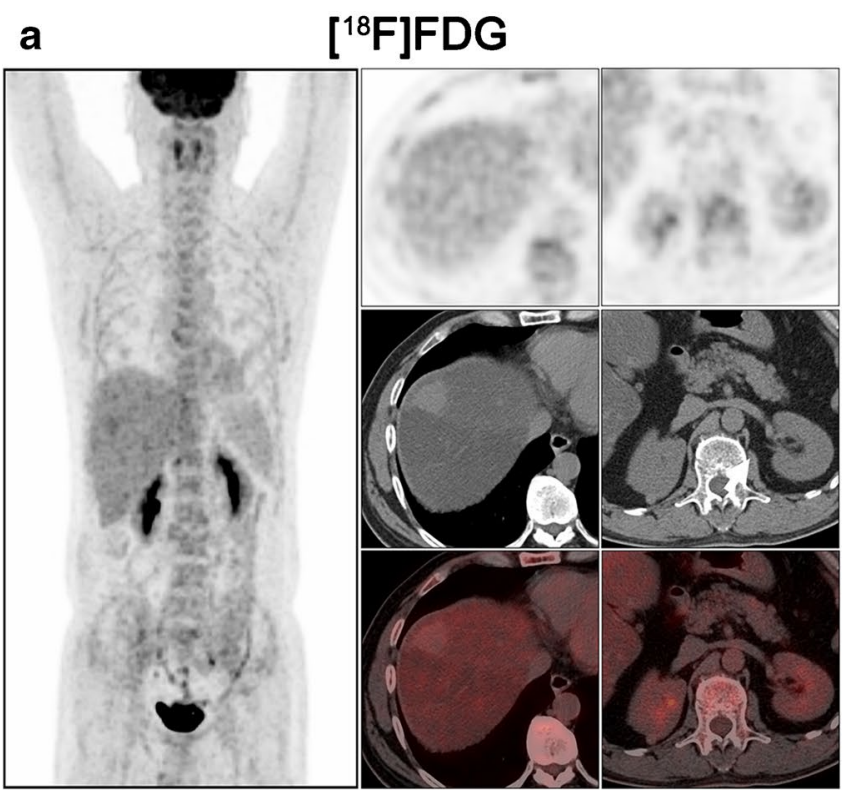

Fig. 5 A 48-year-old man (patient \#45) pathologically confirmed with liver interdigitating dendritic cell sarcoma (IDCS) received radical operation 2 years ago. $\left[{ }^{18} \mathrm{~F}\right]$ FDG PET/CT (a) demonstrated none of the $\left[{ }^{18} \mathrm{~F}\right]$ FDG-avid lesions. Interestingly, $\left[{ }^{68} \mathrm{Ga}\right] \mathrm{Ga}-\mathrm{DOTA}-\mathrm{FAPI}-04$

for TBR, respectively; Table 2 and Table S1). For the other eight subtypes of recurrent STS, $\left[{ }^{68} \mathrm{Ga}\right] \mathrm{Ga}$-DOTA-FAPI-04 had similar performance in assessing local relapse and distant metastasis with $\left[{ }^{18} \mathrm{~F}\right] \mathrm{FDG}$ PET/CT.

Regarding the different grades, both low-grade and highgrade STS showed significantly higher uptake of $\left[{ }^{68} \mathrm{Ga}\right]$ Ga-DOTA-FAPI-04 than $\left[{ }^{18}\right.$ F]FDG $(P<0.001$ and $=0.044$ for $\mathrm{SUV}_{\max }$, respectively; $P<0.001$ and $=0.023$ for TBR, respectively; Table 2 and Table S1). Moreover, $\left[{ }^{18} \mathrm{~F}\right] \mathrm{FDG}$ uptake was higher for high-grade STS compared to lowgrade STS. Conversely, low-grade STS showed higher uptake of $\left[{ }^{68} \mathrm{Ga}\right] \mathrm{Ga}$-DOTA-FAPI-04 than high-grade STS.

\section{Comparison of $\left[{ }^{18} \mathrm{~F}\right]$ FDG and $\left[{ }^{68} \mathrm{Ga}\right] \mathrm{Ga}-\mathrm{DOTA}-\mathrm{FAPI}-04$ PET/CT based on different tissues and organs}

The metastatic lesions were identified in the soft tissues (including muscle, pleura, and peritoneum), lung (Fig. 6), liver, bone, lymph node, spleen, pancreas, and kidney. Regarding different tissues and organs, soft tissues, liver, and bone metastases revealed intensive uptake of [ ${ }^{68} \mathrm{Ga}$ ] Ga-DOTA-FAPI-04 and presented significantly higher semiquantitative values of $\mathrm{SUV}_{\max }$ and TBR than $\left[{ }^{18} \mathrm{~F}\right]$ FDG $\left(P<0.001,<0.001\right.$, and $<0.001$ for $\mathrm{SUV}_{\max }$, respectively; $P=0.015,<0.001$, and $<0.001$ for TBR, respectively; Table 3 and Table S2). Whereas, mean $\mathrm{SUV}_{\max }$ and TBR presented favorable uptake of $\left[{ }^{18} \mathrm{~F}\right] \mathrm{FDG}$ over $\left[{ }^{68} \mathrm{Ga}\right]$ Ga-DOTA-FAPI-04 in lymph node metastases (mean SUVmax $=8.57 \pm 4.45$ vs. $6.26 \pm 4.06, P=0.006$; mean

\section{b $\quad\left[{ }^{68} \mathrm{Ga}\right] \mathrm{Ga}-\mathrm{DOTA}-\mathrm{FAPI}-04$}

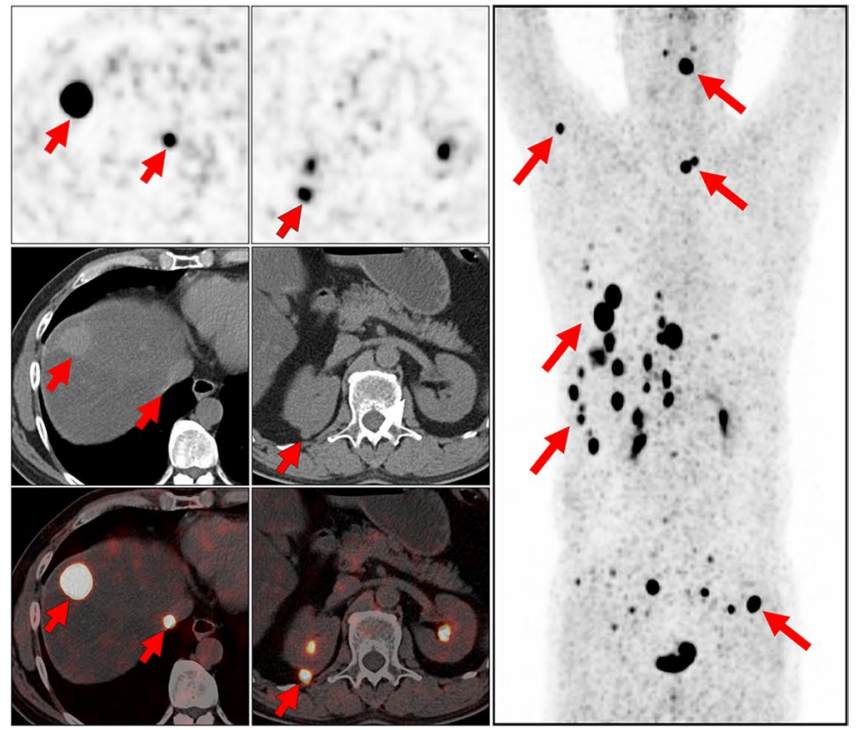

PET/CT (b) demonstrated all the metastatic lesions with intense $\left[{ }^{68} \mathrm{Ga}\right] \mathrm{Ga}$-DOTA-FAPI-04 activity, including liver, right kidney, and bone metastases. Red arrows indicated the tumor lesions detected by $\left[{ }^{68} \mathrm{Ga}\right] \mathrm{Ga}$-DOTA-FAPI-04 alone

$\mathrm{TBR}=11.71 \pm 3.39$ vs. $8.08 \pm 3.95, P=0.011$; Table 3 and Table S2).

$\left[{ }^{68} \mathrm{Ga}\right]$ Ga-DOTA-FAPI-04 outperformed $\left[{ }^{18} \mathrm{~F}\right]$ FDG PET/ $\mathrm{CT}$ in terms of the sensitivity, specificity, PPV, NPV, and accuracy for the diagnosis of recurrent lesions $(P<0.001$, Table 4), and demonstrated significantly higher values of $\mathrm{SUV}_{\max }$ and TBR (mean $\mathrm{SUV}_{\max }=12.64 \pm 15.67 \mathrm{vs}$. $7.76 \pm 4.45, P<0.001$; mean $\mathrm{TBR}=19.03 \pm 31.95$ vs. $10.23 \pm 6.62, P<0.001)$.

\section{Discussion}

This prospective study of 45 patients with 13 subtypes of recurrent STS suggests that $\left[{ }^{68} \mathrm{Ga}\right] \mathrm{Ga}$-DOTA-FAPI-04 PET/ $\mathrm{CT}$ is a promising new imaging modality for recurrent surveillance of STS and provides an enhancement to $\left[{ }^{18} \mathrm{~F}\right] \mathrm{FDG}$ $\mathrm{PET} / \mathrm{CT}$.

STS represents a distinct group of rare malignant tumors with high heterogeneity, which remains a major concern in cancer management [18-20]. Several previous studies [4, $21,22]$ reported the usefulness of $\left[{ }^{18} \mathrm{~F}\right] \mathrm{FDG}$ PET/CT in the diagnosis of primary sarcomas, particularly in high-grade sarcomas. Nevertheless, various subtypes of STS exhibiting a spectrum of atypical imaging appearances may lead to challenge in recurrent surveillance of STS by $\left[{ }^{18} \mathrm{~F}\right] \mathrm{FDG}$ PET/CT [8]. In a prospective trial of 41 patients with clinically suspected tumor relapse of STS, $\left[{ }^{18}\right.$ F]FDG PET/MRI demonstrated higher sensitivity and accuracy and lower 


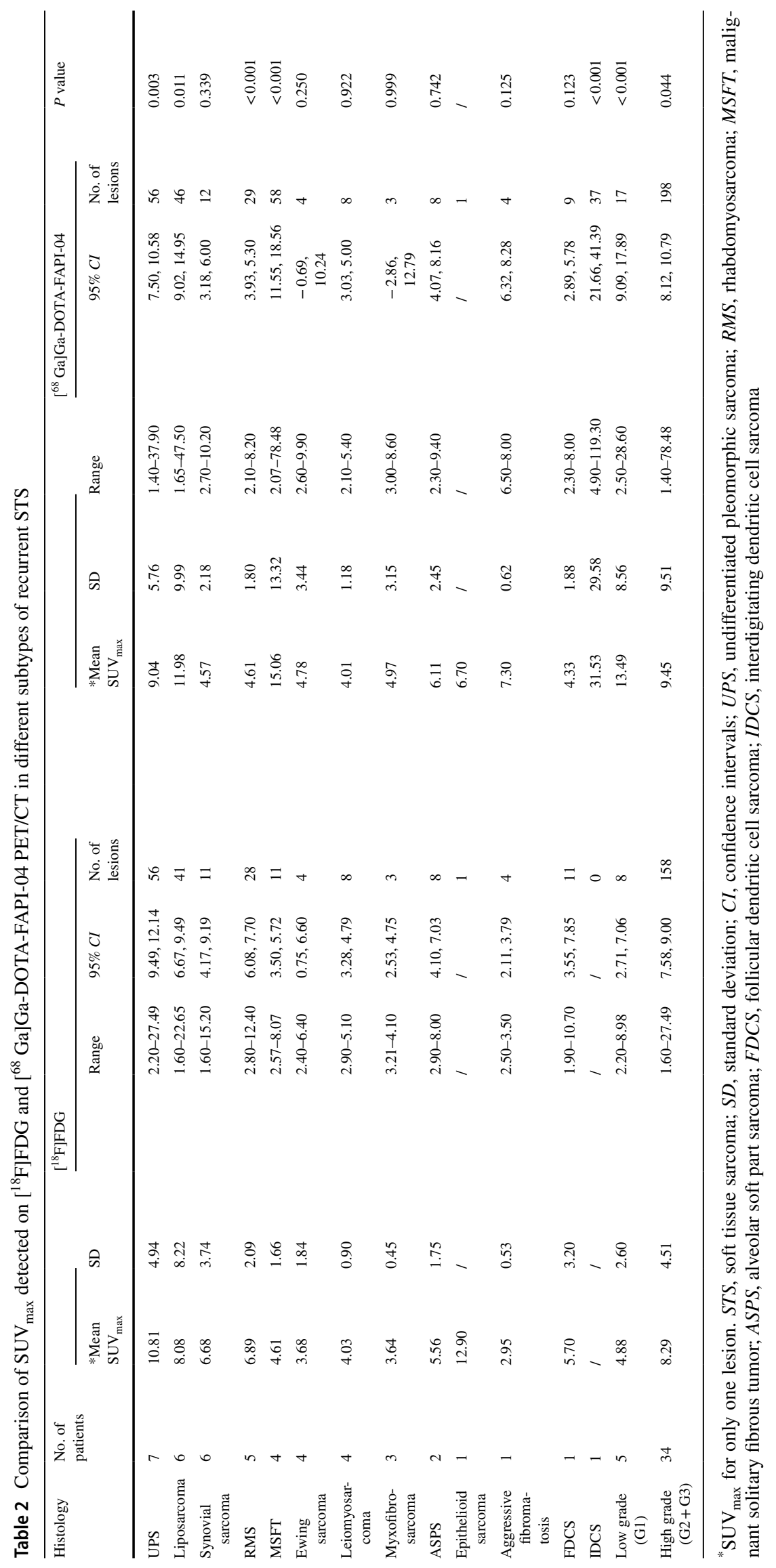


a

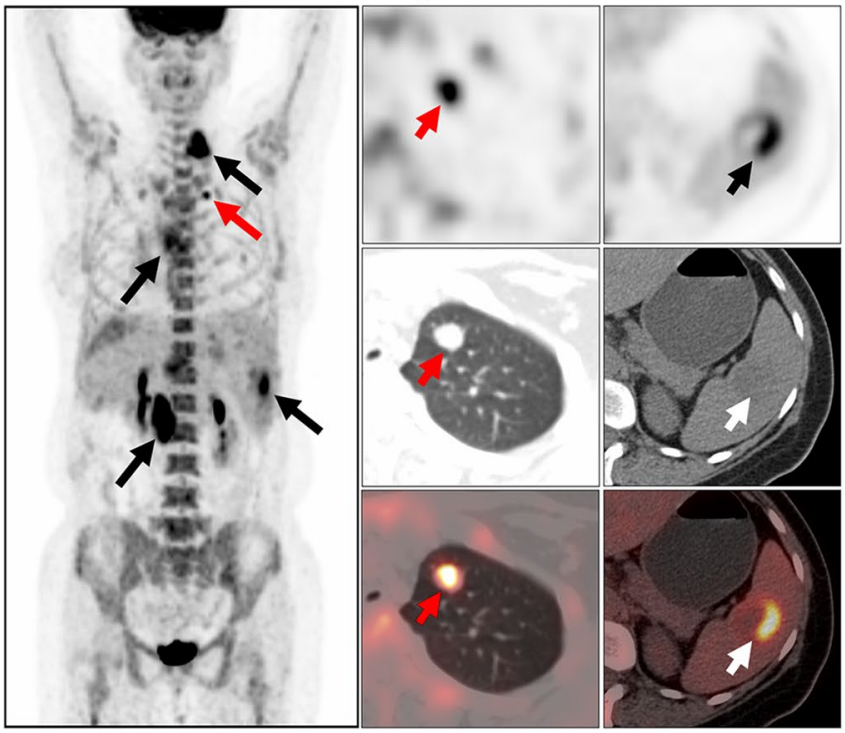

Fig. 6 A 44-year-old woman (patient \#44) pathologically confirmed with liver follicular dendritic cell sarcoma (FDCS) received radical operation 6 months ago. $\left[{ }^{18}\right.$ F]FDG PET/CT (a) demonstrated all the metastatic lesions with intense $\left[{ }^{18} \mathrm{~F}\right] \mathrm{FDG}$ activity, including liver, spleen, lung, and lymph node metastases. Compared with $\left[{ }^{18} \mathrm{~F}\right]$ FDG, $\left[{ }^{68} \mathrm{Ga}\right] \mathrm{Ga}$-DOTA-FAPI-04 PET/CT (b) demonstrated the liver,

specificity for the detection of local tumor recurrence than MRI alone $(95.0 \%$ vs. $80.0 \%, 89.5 \%$ vs. $80.7 \%$, and $76.5 \%$ vs. $82.4 \%$, respectively) [23]. However, in the present study, $\left[{ }^{18} \mathrm{~F}\right] \mathrm{FDG}$ PET/CT detected approximately two-thirds of recurrent lesions with a sensitivity of $65.96 \%$, a specificity of $21.43 \%$, and an accuracy of $61.94 \%$ in the 13 subtypes of STS. Compared to $\left[{ }^{18} \mathrm{~F}\right] \mathrm{FDG},\left[{ }^{68} \mathrm{Ga}\right] \mathrm{Ga}$-DOTAFAPI-04 PET/CT identified almost all lesions (275/282) and presented significant improved sensitivity, specificity, and accuracy $(97.52 \%, 60.71 \%$, and $95.15 \%$, respectively; $P<0.001)$. Furthermore, high PPV for $\left[{ }^{68} \mathrm{Ga}\right] \mathrm{Ga}$-DOTAFAPI-04 PET/CT was also observed in the present study, which is consistent with the results from Kessler et al. (96.15\% vs. $97 \%$ ) [24]. Moreover, the higher sensitivity and accuracy of $\left[{ }^{68} \mathrm{Ga}\right] \mathrm{Ga}-\mathrm{DOTA}-\mathrm{FAPI}-04$ over $\left[{ }^{18} \mathrm{~F}\right]$ FDG PET/ CT could bring benefit in accurately restaging (upstaging in 4 out of 45 patients in the present study and 8 out of 43 patients in Kessler et al. study) and guiding the treatment decision in recurrent STS [24]. Prominent higher uptake of $\left[{ }^{68} \mathrm{Ga}\right] \mathrm{Ga}$-DOTA-FAPI-04 than $\left[{ }^{18} \mathrm{~F}\right]$ FDG was observed in recurrent lesions of STS in terms of mean $\mathrm{SUV}_{\max }$ and TBR $(P<0.001)$, which is in line with previous studies [9, 25]. It should be noted that the intensive uptake of $\left[{ }^{68} \mathrm{Ga}\right]$ Ga-DOTA-FAPI-04 presenting in wound healing, uterus, arthritis, and periodontitis may be misdiagnosed as local relapse or distant metastasis. This is caused by fibrotic activity in these conditions [26]. Thus, more researches focused b $\quad\left[{ }^{68} \mathrm{Ga}\right] \mathrm{Ga}-\mathrm{DOTA}$-FAPI-04

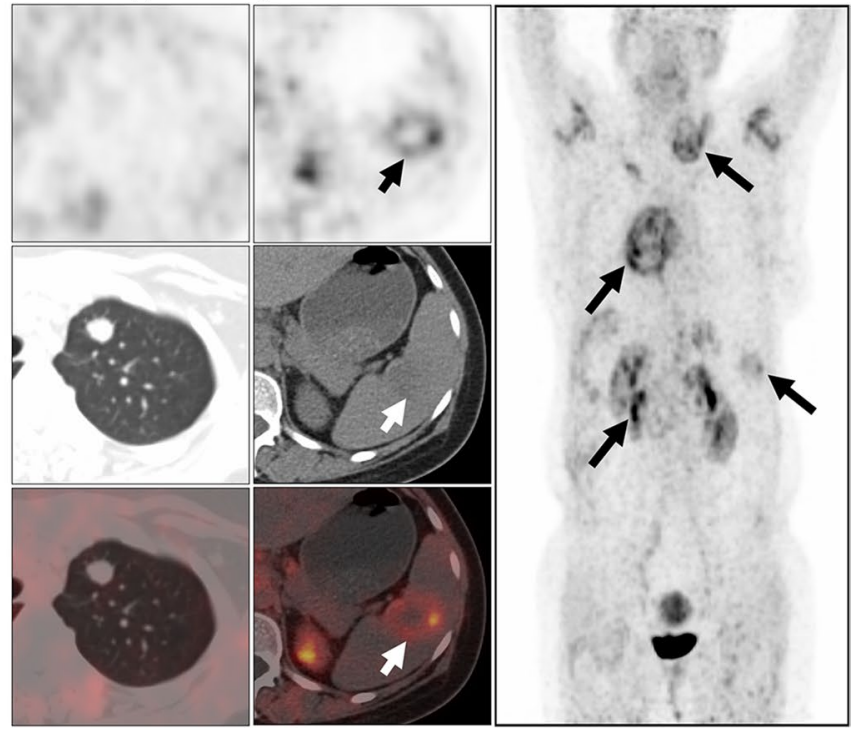

spleen, and lymph node metastases with moderate $\left[{ }^{68} \mathrm{Ga}\right] \mathrm{Ga}$-DOTAFAPI-04 activity. But no intensive $\left[{ }^{68} \mathrm{Ga}\right] \mathrm{Ga}$-DOTA-FAPI-04 uptake was observed on the lung metastatic lesions. Black and white arrows indicated the tumor lesions detected by both tracers, and red arrows indicated the tumor lesions detected by $\left[{ }^{18} \mathrm{~F}\right] \mathrm{FDG}$ alone

on non-tumor-specific uptake of FAPI are still needed [27, 28].

In a recent study, Koerber el al. [25] reported the imaging of seven subtypes of bone and soft tissue sarcoma by FAPI-PET/CT in fifteen patients, demonstrating the high uptake of FAPI for high-grade sarcomas and low uptake for low-grade sarcomas. However, the patient cohort and tumor subtype are small, and the compounds of FAPI are variance (FAPI-04, FAPI-46, and FAPI-74). These factors may result in data bias. In line with previous studies [4, 21], higher $\left[{ }^{18} \mathrm{~F}\right] \mathrm{FDG}$ uptake was also observed in high-grade STS compared to low-grade STS in the present study. However, $\left[{ }^{68} \mathrm{Ga}\right] \mathrm{Ga}$-DOTA-FAPI-04 uptake was lower in high-grade STS than low-grade STS (mean $\mathrm{SUV}_{\max }=9.45$ vs. 13.49) in the present study, which is not consistent with Koerber's research [25]. This may be caused by that the most cases included in the low-grade group were well-differentiated liposarcoma (3/5) and MSFT (1/5), which showed prominent expression of FAP on tumor cell surface [12]. Nevertheless, a significantly higher uptake of $\left[{ }^{68} \mathrm{Ga}\right] \mathrm{Ga}$-DOTA-FAPI-04 was found for high-grade STS compared to $\left[{ }^{18} \mathrm{~F}\right] \mathrm{FDG}$ (mean $\mathrm{SUV}_{\max }=9.45$ vs. $8.29, P=0.044$ ), indicating the potential role of [ $\left.{ }^{68} \mathrm{Ga}\right] \mathrm{Ga}$-DOTA-FAPI-04 PET/CT in detecting recurrent lesions with distinct visual discrimination regardless of tumor grade.

With respect to the diagnostic performance of different relapsed and metastatic lesions, $\left[{ }^{68} \mathrm{Ga}\right] \mathrm{Ga}$-DOTA-FAPI-04 


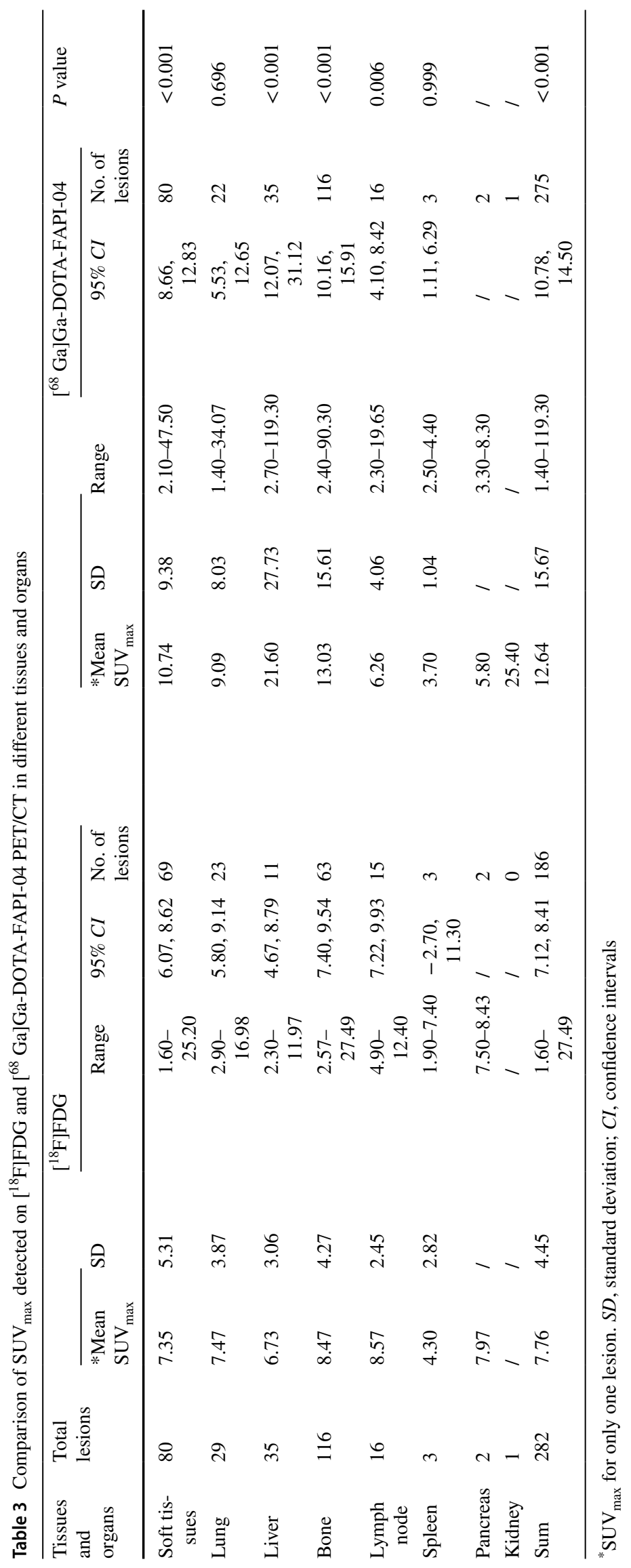


Table 4 Lesion-based statistical analysis of diagnostic performance in $\left[{ }^{18} \mathrm{~F}\right] \mathrm{FDG}$ and $\left[{ }^{68} \mathrm{Ga}\right] \mathrm{Ga}-\mathrm{DOTA}-\mathrm{FAPI}-04$ PET/CT

\begin{tabular}{lcccrr}
\hline Tracer & Sensitivity $(95 \% C I)$ & Specificity $(95 \% C I)$ & PPV $(95 \% C I)$ & NPV $(95 \% C I)$ & Accuracy $(95 \% C I)$ \\
\hline$\left[{ }^{18}\right.$ F]FDG & $65.96(60.25-71.24)$ & $21.43(10.21-39.54)$ & $89.42(84.51-92.91)$ & $5.88(2.72-12.24)$ & $61.94(56.42-67.16)$ \\
{$\left[{ }^{68} \mathrm{Ga}\right]$} & $97.52(94.97-98.79)$ & $60.71(42.41-76.43)$ & $96.15(93.25-97.84)$ & $70.88(50.83-85.09)$ & $94.19(91.01-96.30)$ \\
Ga-DOTA- & & & & & \\
FAPI-04 & & & & & \\
\hline
\end{tabular}

The data was presented as percentage (\%). STS, soft tissue sarcoma; $C I$, confidence intervals; $P P V$, positive predictive value; $N P V$, negative predictive value

PET/CT outperformed $\left[{ }^{18} \mathrm{~F}\right]$ FDG PET/CT in soft tissues, liver, bone, and kidney metastases with improved tumor retention and low background uptake. This advantage of $\left[{ }^{68} \mathrm{Ga}\right]$ Ga-DOTA-FAPI-04 PET/CT over $\left[{ }^{18} \mathrm{~F}\right]$ FDG PET/CT was also demonstrated in many other types of cancer, including head and neck cancers [29], hepatic carcinoma [30], and gastrointestinal cancers [31]. The absence of $\left[{ }^{68} \mathrm{Ga}\right]$ Ga-DOTA-FAPI-04 in normal organs and tissues (e.g., liver, bone, and intestines) will benefit imaging of liver, bone, and abdomen metastases with higher tumor-to-background contrast and better lesion delineation than $\left[{ }^{18} \mathrm{~F}\right] \mathrm{FDG}$ PET/CT. However, it should be noted that $\left[{ }^{68} \mathrm{Ga}\right] \mathrm{Ga}$-DOTA-FAPI-04 was false negative in 7 out of 29 lung metastases (4 from patient \#34 and 3 from patient \#44, Fig. 6). In a recent animal-based study, Ding et al. [32] found that the expression of FAP was prominent in lung metastatic lesion at the early stage but descended during the progress of tumor metastasis. Thus, the diagnostic performance of $\left[{ }^{68} \mathrm{Ga}\right] \mathrm{Ga}$-DOTAFAPI-04 PET in detecting lung metastasis remains uncertain in recurrent STS.

Despite advances in chemotherapy, targeted therapy and immunotherapy over the last decades, the prognosis for patients with metastatic STS remains poor [33]. Limited options with clinical efficacy for the metastatic or local advanced STS existed in addition to standard treatment [2]. Recently, Kratochwil et al. [34] reported a case of metastatic sarcoma treated with ${ }^{90} \mathrm{Y} /{ }^{153} \mathrm{Sm}$-labeled FAPI-46 achieving stable disease for 8 months. Moreover, Ferdinandus et al. [35] demonstrated the potential role of FAP-targeted radioligand therapy in a study of nine patients with solid tumors. Surprisingly, disease control was observed in three patients with sarcomas and one patient with pancreatic ductal adenocarcinoma. These studies indicated that FAP-targeted radioligand therapy may present as a novel promising treatment strategy for incurable recurrent STS. Thus, non-invasive selection of the suitable patients with STS for the coming FAP-targeted radioligand therapy will emerge as a critical issue, and our work serves as a foundation for that.

The major limitation of this study is the relatively low number of patients and limited subtypes of STS. As STS is a large group of malignant tumors, it is hard to enroll all subtypes in a single center. Thus, larger multi-center studies containing more subtypes of STS are still needed to be carried out in the future. Another limitation is that not all $\left[{ }^{68} \mathrm{Ga}\right] \mathrm{Ga}$-DOTA-FAPI-04 and $\left[{ }^{18} \mathrm{~F}\right] \mathrm{FDG}$ positive lesions are pathologically confirmed and examined FAP expression. Nevertheless, these lesions are also verified by continuous follow-up. Furthermore, a positive correlation with $\left[{ }^{68} \mathrm{Ga}\right]$ Ga-DOTA-FAPI-04 uptake and FAP expression is reported in previous study [30].

\section{Conclusion}

The current study demonstrated that $\left[{ }^{68} \mathrm{Ga}\right] \mathrm{Ga}$-DOTAFAPI-04 PET/CT is a promising new imaging modality for recurrent surveillance of STS regardless of tumor grade. [ ${ }^{68} \mathrm{Ga}$ Ga-DOTA-FAPI-04 compared favorably with $\left[{ }^{18} \mathrm{~F}\right] \mathrm{FDG}$ PET/CT for identifying recurrent lesions of liposarcoma, MSFT, and IDCS. For UPS and RMS, $\left[{ }^{18} \mathrm{~F}\right]$ FDG showed a superior diagnostic efficacy than $\left[{ }^{68} \mathrm{Ga}\right]$ Ga-DOTA-FAPI-04 PET/CT. Moreover, $\left[{ }^{68} \mathrm{Ga}\right] \mathrm{Ga}$-DOTAFAPI-04 had similar performance in assessing recurrent surveillance of synovial sarcoma, Ewing sarcoma, leiomyosarcoma, myxofibrosarcoma, alveolar soft part sarcoma (ASPS), aggressive fibromatosis, and follicular dendritic cell sarcoma (FDCS) with $\left[{ }^{18} \mathrm{~F}\right] \mathrm{FDG}$ PET/CT. The clinical value of FAP-targeted radioligand therapy in recurrent STS should be further investigated.

Supplementary Information The online version contains supplementary material available at https://doi.org/10.1007/s00259-022-05700-4.

Funding This work was funded by the National Key Research and Development Program of China (Grant number 2020YFA0909000), National Natural Science Foundation of China (Grant number 81771861, 81971648, and 81901778), and Shanghai Anticancer Association Program (Grant number HYXH2021004).

Data availability The datasets used and analyzed during the current study are available from the corresponding author on reasonable request. 


\section{Declarations}

Ethics approval All procedures involving human participants were carried out in accordance with the ethical standards of the institutional and/or national research committee and with the 1964 Helsinki Declaration and its later amendments or comparable ethical standards. This article does not contain any experiments with animals.

Consent to participate Informed consents were obtained from all individual participants included in the study.

Conflict of interest The authors declare no competing interests.

Open Access This article is licensed under a Creative Commons Attribution 4.0 International License, which permits use, sharing, adaptation, distribution and reproduction in any medium or format, as long as you give appropriate credit to the original author(s) and the source, provide a link to the Creative Commons licence, and indicate if changes were made. The images or other third party material in this article are included in the article's Creative Commons licence, unless indicated otherwise in a credit line to the material. If material is not included in the article's Creative Commons licence and your intended use is not permitted by statutory regulation or exceeds the permitted use, you will need to obtain permission directly from the copyright holder. To view a copy of this licence, visit http://creativecommons.org/licenses/by/4.0/.

\section{References}

1. WHO Classification of Tumors Editorial Board. WHO classification of tumours of soft tissue and bone. 5th ed. Lyon, France: IARC Press; 2020.

2. Comandone A, Petrelli F, Boglione A, Barni S. Salvage therapy in advanced adult soft tissue sarcoma: a systematic review and metaanalysis of randomized trials. Oncologist. 2017;22(12):1518-27. https://doi.org/10.1634/theoncologist.2016-0474.

3. Gamboa AC, Gronchi A, Cardona K. Soft-tissue sarcoma in adults: an update on the current state of histiotype-specific management in an era of personalized medicine. CA Cancer J Clin. 2020;70(3):200-29. https://doi.org/10.3322/caac.21605.

4. Macpherson RE, Pratap S, Tyrrell H, Khonsari M, Wilson S, Gibbons M, et al. Retrospective audit of 957 consecutive (18) F-FDG PET-CT scans compared to CT and MRI in 493 patients with different histological subtypes of bone and soft tissue sarcoma. Clin Sarcoma Res. 2018;8:9. https://doi.org/10.1186/ s13569-018-0095-9.

5. Ha SC, Oh JS, Roh JL, Moon H, Kim JS, Cho KJ, et al. Pretreatment tumor SUVmax predicts disease-specific and overall survival in patients with head and neck soft tissue sarcoma. Eur J Nucl Med Mol Imaging. 2017;44(1):33-40. https://doi.org/10. 1007/s00259-016-3456-8.

6. Salaün PY, Abgral R, Malard O, Querellou-Lefranc S, Quere G, Wartski M, et al. Good clinical practice recommendations for the use of PET/CT in oncology. Eur J Nucl Med Mol Imaging. 2020;47(1):28-50. https://doi.org/10.1007/s00259-019-04553-8.

7. Noebauer-Huhmann IM, Weber MA, Lalam RK, Trattnig S, Bohndorf K, Vanhoenacker F, et al. Soft tissue tumors in adults: ESSRapproved guidelines for diagnostic imaging. Semin Musculoskelet Radiol. 2015;19(5):475-82. https://doi.org/10.1055/s-0035-15692 51.

8. Benz MR, Crompton JG, Harder D. PET/CT variants and pitfalls in bone and soft tissue sarcoma. Semin Nucl Med. 2021;51(6):584-92. https://doi.org/10.1053/j.semnuclmed.2021. 06.009 .
9. Kratochwil C, Flechsig P, Lindner T, Abderrahim L, Altmann A, Mier W, et al. (68)Ga-FAPI PET/CT: tracer uptake in 28 different kinds of cancer. J Nucl Med. 2019;60(6):801-5. https://doi.org/ 10.2967/jnumed.119.227967.

10. Koczorowska MM, Tholen S, Bucher F, Lutz L, Kizhakkedathu JN, De Wever O, et al. Fibroblast activation protein-alpha, a stromal cell surface protease, shapes key features of cancer associated fibroblasts through proteome and degradome alterations. Mol Oncol. 2016;10(1):40-58. https://doi.org/10.1016/j.molonc.2015. 08.001 .

11. Scanlan MJ, Raj BK, Calvo B, Garin-Chesa P, Sanz-Moncasi MP, Healey JH, et al. Molecular cloning of fibroblast activation protein alpha, a member of the serine protease family selectively expressed in stromal fibroblasts of epithelial cancers. Proc Natl Acad Sci USA. 1994;91(12):5657-61. https://doi.org/10.1073/ pnas.91.12.5657.

12. Rettig WJ, Garin-Chesa P, Beresford HR, Oettgen HF, Melamed MR, Old LJ. Cell-surface glycoproteins of human sarcomas: differential expression in normal and malignant tissues and cultured cells. Proc Natl Acad Sci USA. 1988;85(9):3110-4. https://doi. org/10.1073/pnas.85.9.3110.

13. Dohi O, Ohtani H, Hatori M, Sato E, Hosaka M, Nagura H, et al. Histogenesis-specific expression of fibroblast activation protein and dipeptidylpeptidase-IV in human bone and soft tissue tumours. Histopathology. 2009;55(4):432-40. https://doi.org/10. 1111/j.1365-2559.2009.03399.x.

14. Lindner T, Loktev A, Altmann A, Giesel F, Kratochwil C, Debus $\mathrm{J}$, et al. Development of quinoline-based theranostic ligands for the targeting of fibroblast activation protein. J Nucl Med. 2018;59(9):1415-22. https://doi.org/10.2967/jnumed.118.210443.

15. Chen H, Zhao L, Ruan D, Pang Y, Hao B, Dai Y, et al. Usefulness of [(68)Ga]Ga-DOTA-FAPI-04 PET/CT in patients presenting with inconclusive [(18)F]FDG PET/CT findings. Eur J Nucl Med Mol Imaging. 2021;48(1):73-86. https://doi.org/10.1007/ s00259-020-04940-6.

16. Chen H, Pang Y, Wu J, Zhao L, Hao B, Wu J, et al. Comparison of $[(68) \mathrm{Ga}] \mathrm{Ga}-\mathrm{DOTA}-F A P I-04$ and [(18)F] FDG PET/ $\mathrm{CT}$ for the diagnosis of primary and metastatic lesions in patients with various types of cancer. Eur J Nucl Med Mol Imaging. 2020;47(8):1820-32. https://doi.org/10.1007/ s00259-020-04769-z.

17. Eisenhauer EA, Therasse P, Bogaerts J, Schwartz LH, Sargent D, Ford R et al. New response evaluation criteria in solid tumours: revised RECIST guideline (version 1.1). Eur J Cancer. 2009;45(2):228-47. https://doi.org/10.1016/j.ejca.2008.10.026.

18. Dagogo-Jack I, Shaw AT. Tumour heterogeneity and resistance to cancer therapies. Nat Rev Clin Oncol. 2018;15(2):81-94. https:// doi.org/10.1038/nrclinonc.2017.166.

19. Lee JW, Park JY, Lee HJ, Lee JJ, Moon SH, Kang SY, et al. Preoperative [(18)F]FDG PET/CT tumour heterogeneity index in patients with uterine leiomyosarcoma: a multicentre retrospective study. Eur J Nucl Med Mol Imaging. 2018;45(8):1309-16. https:// doi.org/10.1007/s00259-018-3975-6.

20. Annovazzi A, Ferraresi V, Anelli V, Covello R, Vari S, Zoccali C, et al. [(18)F]FDG PET/CT quantitative parameters for the prediction of histological response to induction chemotherapy and clinical outcome in patients with localised bone and soft-tissue Ewing sarcoma. Eur Radiol. 2021;31(9):7012-21. https://doi.org/ 10.1007/s00330-021-07841-w.

21. Charest M, Hickeson M, Lisbona R, Novales-Diaz JA, Derbekyan $\mathrm{V}$, Turcotte RE. FDG PET/CT imaging in primary osseous and soft tissue sarcomas: a retrospective review of 212 cases. Eur J Nucl Med Mol Imaging. 2009;36(12):1944-51. https://doi.org/10. 1007/s00259-009-1203-0.

22. Lim HJ, Johnny Ong CA, Tan JW, Ching Teo MC. Utility of positron emission tomography/computed tomography (PET/CT) 
imaging in the evaluation of sarcomas: a systematic review. Crit Rev Oncol Hematol. 2019;143:1-13. https://doi.org/10.1016/j. critrevonc.2019.07.002.

23. Erfanian Y, Grueneisen J, Kirchner J, Wetter A, Podleska LE, Bauer S, et al. Integrated ${ }^{18}$ F-FDG PET/MRI compared to MRI alone for identification of local recurrences of soft tissue sarcomas: a comparison trial. Eur J Nucl Med Mol Imaging. 2017;44(11):1823-31. https://doi.org/10.1007/ s00259-017-3736-y.

24. Kessler L, Ferdinandus J, Hirmas N, Bauer S, Dirksen U, Zarrad F, et al. Ga-68-FAPI as diagnostic tool in sarcoma: data from the FAPI-PET prospective observational trial. J Nucl Med. 2022;63(1):89-95. https://doi.org/10.2967/jnumed.121.262096.

25. Koerber SA, Finck R, Dendl K, Uhl M, Lindner T, Kratochwil $\mathrm{C}$, et al. Novel FAP ligands enable improved imaging contrast in sarcoma patients due to FAPI-PET/CT. Eur J Nucl Med Mol Imaging. 2021;48(12):3918-24. https://doi.org/10.1007/ s00259-021-05374-4.

26. Dendl K, Koerber SA, Kratochwil C, Cardinale J, Finck R, Dabir $\mathrm{M}$, et al. FAP and FAPI-PET/CT in malignant and non-malignant diseases: a perfect symbiosis? Cancers (Basel). 2021;13(19):4946. https://doi.org/10.3390/cancers13194946.

27. Kessler L, Ferdinandus J, Hirmas N, Zarrad F, Nader M, Kersting D, et al. Pitfalls and common findings in (68)Ga-FAPI-PET - a pictorial analysis. J Nucl Med. 2021. https://doi.org/10.2967/ jnumed.121.262808.

28. Qin C, Song Y, Liu X, Gai Y, Liu Q, Ruan W, et al. Increased uptake of (68)Ga-DOTA-FAPI-04 in bones and joints: metastases and beyond. Eur J Nucl Med Mol Imaging. 2021. https://doi.org/ 10.1007/s00259-021-05472-3.

29. Syed M, Flechsig P, Liermann J, Windisch P, Staudinger F, Akbaba S, et al. Fibroblast activation protein inhibitor (FAPI) PET for diagnostics and advanced targeted radiotherapy in head and neck cancers. Eur J Nucl Med Mol Imaging. 2020;47(12):283645. https://doi.org/10.1007/s00259-020-04859-y.
30. Shi X, Xing H, Yang X, Li F, Yao S, Zhang H, et al. Fibroblast imaging of hepatic carcinoma with (68)Ga-FAPI-04 PET/CT: a pilot study in patients with suspected hepatic nodules. Eur J Nucl Med Mol Imaging. 2021;48(1):196-203. https://doi.org/10.1007/ s00259-020-04882-z.

31. Pang Y, Zhao L, Luo Z, Hao B, Wu H, Lin Q, et al. Comparison of (68)Ga-FAPI and (18)F-FDG uptake in gastric, duodenal, and colorectal cancers. Radiology. 2021;298(2):393-402. https://doi. org/10.1148/radiol.2020203275.

32. Ding F, Huang C, Liang C, Wang C, Liu J, Tang D. (68) Ga-FAPI-04 vs. (18)F-FDG in a longitudinal preclinical PET imaging of metastatic breast cancer. Eur J Nucl Med Mol Imaging. 2021;49(1):290-300. https://doi.org/10.1007/ s00259-021-05442-9.

33. Frezza AM, Stacchiotti S, Gronchi A. Systemic treatment in advanced soft tissue sarcoma: what is standard, what is new. BMC Med. 2017;15(1):109. https://doi.org/10.1186/s12916-017-0872-y.

34. Kratochwil C, Giesel FL, Rathke H, Fink R, Dendl K, Debus $\mathrm{J}$, et al. [(153)Sm]Samarium-labeled FAPI-46 radioligand therapy in a patient with lung metastases of a sarcoma. Eur J Nucl Med Mol Imaging. 2021;48(9):3011-3. https://doi.org/10.1007/ s00259-021-05273-8.

35. Ferdinandus J, Fragoso Costa P, Kessler L, Weber M, Hirmas N, Kostbade K, et al. Initial clinical experience with (90)Y-FAPI-46 radioligand therapy for advanced stage solid tumors: a case series of nine patients. J Nucl Med. 2021. https://doi.org/10.2967/ jnumed.121.262468.

Publisher's note Springer Nature remains neutral with regard to jurisdictional claims in published maps and institutional affiliations. 